\title{
On extending the truncated parameters of transformation in higher education in South Africa into a language of democratic engagement and justice
}

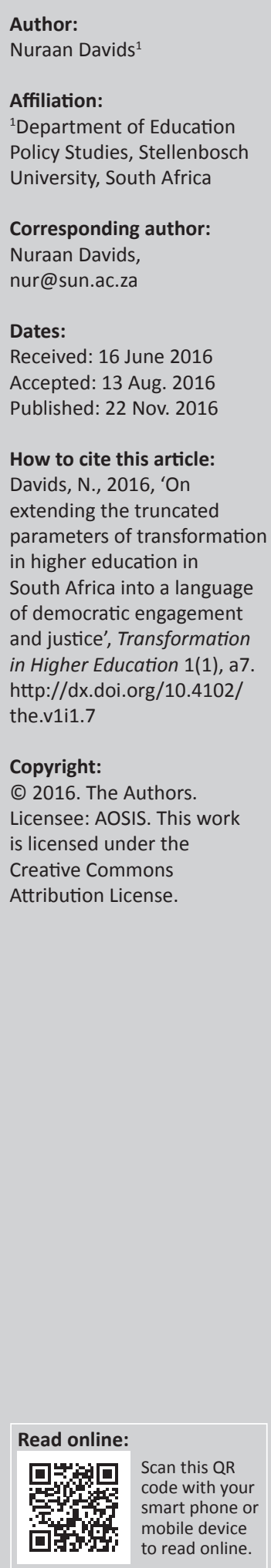

\begin{abstract}
Universities, in their multiplex roles of social, political, epistemological and capital reform, are by their constitution expected to both symbolise and enact transformation. While institutions of higher education in South Africa have been terrains of protest and reform - whether during apartheid or post-apartheid - the intense multiplex roles which these institutions assume have metaphorically come home to roost in the past 2 years. Not unlike the social-media-infused rumblings, coined as the 'Arab Spring', the recent cascades of \#mustfall campaigns have brought to the fore the serious dearth of transformation in higher education and have raised more critical questions about conceptions of transformation, and how these translate into, or reflect, the social and political reform that continues to dangle out of the reach of the majority of South Africans. What, then, does transformation mean and imply? How does an institution reach a transformed state? How does one know when such a state is reached? These are a few of the concerns this article seeks to address. But it hopes to do so by moving beyond the thus far truncated parameters of transformation - which have largely been seeped in the oppositional politics of historical advantage and disadvantage, and which, in turn, have ensured that conceptions of transformation have remained trapped in discourses of race and racism. Instead, this article argues that the real challenge facing higher education is not so much about transformation, as it is about enacting democracy through equipping students to live and think differently in a pluralist society.
\end{abstract}

\section{On undifferentiating higher education in South Africa}

Prior to 1994, the differentiated higher education system comprised 26 public universities, 15 technikons (polytechnics), 120 colleges of education, 24 nursing colleges and 11 agricultural colleges, which all differed in terms of quality of academic provision, adequacy of infrastructure and facilities, and the level of state investment and funding (HESA 2014:9). With the advent of constitutional democracy in 1994, and the subsequent promulgation of the government's White Paper 3: A Programme for the Transformation of Higher Education by the then Department of Education (DoE) in 1997, the higher education system was subsequently completely overhauled as an integrated, 'single, national co-ordinated system that would ensure diversity in its organisational form and the institutional landscape, mix of institutional missions and programmes commensurate with national and regional needs in social, cultural and economic development' (DoE 1997:2.3). To Badat (2010:3), the social purposes that higher education was intended to serve, as identified in the White Paper 3, resonate with the core roles of higher education of disseminating knowledge and producing critical graduates, producing and applying knowledge through research and development activities and contributing to economic and social development and democracy through learning and teaching, research and community engagement.

The White Paper 3 (DoE 1997) was followed by the Higher Education Amendment Act (DoE 1998), which, in turn, was followed by the National Plan for Higher Education (DoE 2001). Motivating these education policy initiatives has been a committed drive, on the one hand, to differentiate postapartheid higher education from its widely disparate past, and, on the other hand, it attempts to satisfy utilitarian demands in the service of the government and the public. Consequently, one finds that the National Plan for Higher Education (DoE 2001) proposes the achievement of 16 outcomes which range from increasing student access, particularly of black communities into the university sector, to enhancing their (students') cognitive abilities with respect to technical and professional competences that would not only ensure greater competitiveness in an ever-evolving labour market economy but also increased participation as democratic citizens in service of the 'public good'.

Note: Some of the research and writing of this article is based on work previously published by the author. Please see links to published work: http://link.springer.com/book/10.1007\%2F978-94-6209-476-5; http://www.journals.ac.za/index.php/sajhe/article/downloaded/ $554 / 142$ 
By 2001, the colleges of education were either closed or incorporated into the universities and technikons, and the 36 higher education institutions (HEIs) were either merged, unbundled or incorporated to form 11 traditional (research) universities that offer largely degree programmes, 6 comprehensive universities (one distance education institution in the form of the University of South Africa [Unisa]) and 6 universities of technology. In addition, 2 institutes of higher education were established in provinces without universities, namely the Northern Cape and Mpumalanga - 2 of 9 provinces in the country - in 2013. Thus, it was envisaged that the post-1994 institutional restructuring would engender a differentiated, diverse and articulated higher education system that resonated with the knowledge and development needs of South Africa and the imperative of achieving social justice (HESA 2014:10).

As acknowledged by Higher Education South Africa (HESA), a new, differentiated higher education institutional landscape has not adequately and justifiably addressed the past inequities, more specifically as they relate to the educational, material, financial and geographical elements of the (white) advantaged and the (black) disadvantaged (2014):

The continued under-developed institutional capacities of historically black institutions must be emphasized; providing access to rural poor and working class black students, inadequate state support for the historically black institutions to equalize the quality of undergraduate provision compromises their ability to facilitate equity of opportunity and outcomes. (p. 11)

This view is corroborated by the Department of Higher Education and Training (DHET) in their Green Paper of 2012:

$[A]$ diverse university system steeped in inequality is the product of apartheid education policies, and that reality still confronts us today. While our leading universities are internationally respected, our historically black universities continue to face severe financial, human, infrastructure and other resource constraints. Universities of Technology are in some instances experiencing mission drift, losing focus on their mission of producing technicians, technologists and other mid-level skills at undergraduate level. This problem is also evident in the comprehensive universities. (p. 11)

Following on the above, it is, of course, important to make sense of why this new differentiated higher education institutional landscape has not adequately and justifiably addressed the past inequities. One set of explanations resides in the reality that higher education in South Africa has certainly not been immune to the types of transformation practices that have largely been couched in languages of corporatisation. The corporatisation of higher education, state Aronowitz and Giroux (2000:333), has reformulated social issues as largely individual or economic considerations, cancelling out democratic impulses by either devaluing them or absorbing such impulses within the imperatives of the marketplace. In their opinion, as corporate culture and values shape university life, corporate planning replaces social planning, management becomes a substitute for leadership and the private domain of individual achievement replaces the discourse of public politics and social responsibility. In a climate of increasing justification of expenditure and the demonstration of 'value for money', explains Deem (1998:47), those who run universities are expected to ensure that such value is provided and their role as academic leaders is being subsumed by a greater concern with the overt management of sites, finance, staff, students, teaching and research.

In turn, Peters (2007:160) explains that, as in Anglophone countries, higher education in South Africa has transformed from a universal welfare entitlement into a human capital private investment, which has prompted the higher education sector to adapt its educational leadership commensurate to its commitment to free market principles. Firstly, states Peters (2007:160), the university sector introduced new forms of corporate managerialism and the emulation of private sector management styles. Secondly, the corporatisation of the university system with its emphasis on accountability and efficiency resulted in new forms of delegated authority. Thirdly, with the introduction of corporate or strategic planning for the university sector to reduce its alleged financial risks, more bureaucratic forms of university governance were instituted at the cost of discrediting democratic governance (Peters 2007:160). The other set of possible explanations, which is the focus of this article, is located in the language of transformation itself.

\section{On the underbelly of transformation}

Badat (2010:7) observes that there has been an intractable tension between a number of values and goals of higher education. The extent to which government and universities have sought to pursue social equity and redress and quality in higher education simultaneously, continues Badat (2010:7), has resulted in difficult political and social dilemmas. Primary among these dilemmas is inadequate public finances and academic development initiatives to support underprepared students, who tend to be largely black and/or of working class or rural poor social origins. Badat (2010) explains that:

An exclusive concentration on social equity and redress without adequate public funding and academic development initiatives to support under-prepared students has negative implications for quality, compromises the production of high quality graduates with the requisite knowledge competencies and skills, and adversely affects economic development. Conversely, an exclusive focus on economic development and quality and 'standards', (especially when considered to be timeless and invariant and attached to a single, a-historical and universal model of higher education) results in equality being retarded or delayed with limited erosion of the racial and gender character of the high-level occupational structure. (p. 7)

What the aforementioned shows, says Badat (2010:7), is that the transformation agenda in higher education embodies paradoxes, which not only necessarily raise social and political dilemmas but also create the types of responses characterised through the \#mustfall campaigns. In 2015, 
higher education in South Africa has come to resemble exactly the 'distortion, upheaval and fragmentation that marked the sector at the start of the 1990s' (Jansen 2004:293). The upheaval, according to Hall (2016), began in the north, at Tshwane University of Technology, when students were prevented from registering because of outstanding fee debts. This, he explains, was exacerbated by the inability of the state loan and bursary agency - the National Student Financial Aid Scheme (NSFAS) - to meet its commitments. Confrontations spread to other campuses, explains Hall (2016), and next to act were students in the south. While students at the University of Cape Town took issue with the legacy of colonialism, symbolised by the memorial to Cecil John Rhodes, students at Stellenbosch distributed a powerfully evocative film - 'Luister' (Listen) - that documented black students' daily experiences of racism and discrimination (Hall 2016). While the \#RhodesMustFall campaign might have been perceived as a call for the removal of a statue, the campaign was, in fact, intricately embedded in deeper demands for the decolonisation of higher education, which are tied not only to achieving racially balanced institutions - as facilitated through access - but are also about the perceived 'whiteness' of higher education spaces. In this regard, the 2012 statistics revealed that in spite of the whites constituting only around $8 \%$ of the population, white academics constituted $53 \%$ of full-time permanent staff, of which 55\% were male (HESA 2014). Although gradually shifting, the poor representation of black academics in higher education is exacerbated by the insufficient cohort of PhD graduates. In this regard, South African universities, according to the HESA report (2014), are confronted with two challenges. The first pertains to the production and retention of the next generation of academics. And the second challenge relates to transforming the social composition of the academic work force through measures that advance social equity and redress for black people and women.

Following \#RhodesMustFall' came the \#FeesMustFall campaign in October 2015 - initiated by students at the University of Witwatersrand in response to student fee increases for 2016. In addition to the demand for the suspension of fee increases and upfront payments, students also demanded concessions for financially impoverished students, and that out-sourced services be in-sourced. Thanks to the reach of social media, the hashtags \#RhodesMustFall and \#FeesMustFall soon garnered tremendous support across political and social spectrums - from students, and academics, to university workers and politicians. In response, the Ministry of Higher Education and Training convened a 'transformation' summit in mid-October 2015 attended by key stakeholders. Not surprisingly, the summit was followed by large-scale, and increasingly violent, protests and clashes with police at a number of universities, as well as at parliament. No doubt, the violent and destructive nature of the protests - with university buildings, libraries and hostels being destroyed - played a huge role in President Zuma's announcement that there would be no student fee increases in 2016. However, as Badat (2016:13) points out, the 'transformation' summit' offered no direction on how higher education would be adequately funded to address various needs, including student demands related to fees and financial aid.

To Badat (2016:3), the economic dimension of the \#FeesMustFall campaign is evident in the fact that, on the one hand, South African higher education is inadequately funded by the state. He continues that the block grant to universities has declined in real terms as has, therefore, the per capita contribution per student, thereby forcing universities to make up the shortfall through increasing tuition fees, seeking third-stream income and reducing costs through mechanisms such as outsourcing. On the other hand, states Badat (2016:3), the level of state funding for financial aid for students who are academically eligible for admission to universities and meet the criteria of the largely state-funded NSFAS is inadequate to support all deserving students at appropriate levels for undergraduate and postgraduate study. To this end, Badat (2016) maintains that:

It is not that the state is unaware of the challenges or the measures that are required to ensure that higher education addresses effectively equity, quality, and development problems, or that the higher education budget has not increased, or that funds have not been provided to address important issues and areas. The simple reality is that state funding has been inadequate to support universities to discharge their critical purposes of producing knowledge, cultivating high quality graduates, and engaging meaningfully with diverse communities, to play the diverse roles they must to help realize environmentally sustainable economic development, equity, social justice, and a vibrant democracy, and do all this in a way that ensures that the necessary transformations related to equity, the nature and quality of learning and teaching, research, and institutional culture also occur simultaneously within higher education. (p. 4)

$\mathrm{Du}$ Toit (2000:93) states that adding to the challenges of insufficient funds for tuition, subsistence and accommodation is the prospect of large debt, high drop-out rates, poor throughput rates, inadequate facilities and accommodation, largely unreconstructed epistemologies and ontologies, questionable quality of learning and teaching to ensure meaningful opportunities and success, and alienating and disempowering academic and institutional cultures that are suffused by 'whiteness', and are products of the historical 'legacies of intellectual colonisation and racialization'.

\section{Transformation as disruption and violence?}

In light, then, of the aforementioned discussions, it becomes evident, as expressed by Badat (2016:19), that the 2015-2016 student protests serve as a dramatic reminder of unfinished business in higher education. These protests have forcefully placed key issues on the agenda: the decolonisation of the university; the social composition of academic staff; institutional culture; the inadequacy of state funding of higher education; the level and escalation of tuition fees; student debt; and the question of free higher education. And, perhaps, 
the key word in Badat's analysis is 'forcefully' - in that one cannot ignore that inasmuch as protests have united students across race, class and ideologies, the protests, as MacGregor (2016) observes, have been notably characterised by violence, wanton destruction to property and arson. Violence at South Africa's universities, states Hall (2016), has escalated from damaging statues and artworks and confrontations with security staff and police, to the burning of buildings and brutal clashes between student factions. Underlying these violent clashes - which the government has recently estimated in excess of R350 million - says Hall (2016), are the legacies of racial discrimination and colonialism, high levels of unemployment and pronounced and increasing income inequality. In this regard, Hall (2016) submits that the university crisis has shown how race and history continue to permeate almost every aspect of South Africa's public life.

In agreement with Hall (2016), Suttner (2016) states that key features of the structural architecture of South African society have remained the same, despite gains that have been made. To this end, says Suttner (2016), the experiences of most black people in South Africa remain troubling continuities of the apartheid era and its racism. To Suttner (2016), the \#FeesMustFall and \#RhodesMustFall campaigns may raise wider questions that go beyond the educational realm and offer a prism through which we can look at post-1994 South Africa and ask troubling questions about the nature of this society. Primary among these, which I will now focus my attention on, is what Suttner (2016) describes as the 'readiness of some to resort to violence or the rhetoric of violence-assolution'.

Historically, and particularly in relation to disadvantaged institutions, sites of learning (universities, schools) in South Africa have always been sites of protest and violence. Like schools, universities have young, impressionable and volatile youth - characteristics that bode well for political activism as perhaps, most vividly encountered in the 1976 Soweto uprisings against the imposition of Afrikaans as a medium of instruction. Such was the impact of the Soweto uprisings that it seemingly legitimised the use of education and educational institutions as a weapon against perceptions and experiences of oppression, inequality and exclusion. Of course, there is nothing unique about the relationship between sites of learning/students and violence. It was a Tunisian university graduate (Mohamed Bouazzizi), for instance, who, through self-immolation, set in motion the political cascade, which became commonly known as the 'Arab Spring'. Similarly, pro-Mohamed Morsi students protested at several universities across Egypt in 2014, resulting in clashes with security forces (Barsoum 2014). Lange's (2012:190) contention, therefore, that educated individuals are more likely to commit violent acts than those who are uneducated is an unsurprising one. This is because educated individuals have skills, access to resources, as well as the oratory ability to mobilise both educated and uneducated individuals to join them in their endeavours (Lange 2012:190).
In turn, Sanborn and Thyne (2011:2) contend that the more students pursue higher levels of education within contexts of social and economic insecurity and inequality, the more knowledgeable they become about the world around them, and the more, therefore, they seek to distinguish themselves with profitable skill sets, and are more likely to push for political change, of which they have become aware through education.

If we agree on the potential role that protest and violence might play in bringing about reform and transformation - as it has, thus far, in transitioning apartheid South Africa to a democratic society - then it might be worthwhile to consider Mouffe's (2000:130-131) argument that not only is violence an accepted part of human nature, but it is part of something called the 'dimension of the political'. For Mouffe (2000), the political nature of democracy necessarily means that while some are included, others will be excluded. According to Mouffe (1992), inasmuch as we need to be upfront about these exclusions - as a means to understand why they have been excluded from the political community - we need to understand 'Rivalry and violence, far from being the exterior of exchange, are therefore its ever-present possibility. Reciprocity and hostility cannot be disassociated, and we have to realise that the social order will always be threatened by violence' (Mouffe 2000:131). She continues that the rationalist view of human nature, which denies the negative traits within society - such as violence - is not the necessary basis for democracy, but is instead its weakest point. 'By foreclosing the recognition that violence is ineradicable, it renders democratic theory unable to grasp the nature of "the political" in its dimension of hostility and antagonism' (Mouffe 2000:132).

To Mouffe, politics is not something that happens inside the political community; rather, politics constitutes the political community. This means that, when a conception of 'we' is constructed - as South Africa has been attempting to do since its first democratic elections - then the political community requires the correlative idea of the common good - that is, 'something to which we must constantly refer but that can never be reached' (Mouffe 1992:30). Of significance for postapartheid South Africa is that, in such a view, the common good functions, as a 'social imaginary', meaning that the 'very impossibility of achieving full representation gives to it the role of a horizon that is the condition of possibility of any representation within the space that it delimits' (Mouffe 1992:30). Mouffe (1992:30) stresses that, in constructing a 'we' that is necessarily based on acts of exclusion (and possible violation), the condition of possibility of the political community is at the same time the condition of impossibility of its full realisation.

The argument here is not that violence ought to be legitimised, or justified; it simply means that agonism and agonistic forms of engagement are a necessary part of any political community, and a necessary condition for democratic engagement. Mouffe (2007:3) considers 'agonistic' struggle as 
the very configuration of power relations around which a given society is structured. Higher education, as powerful sites of learning - in a Foucauldian sense - will never be without resistance. As Giroux and Samalavicius (2016) emphasise, it must be made clear to a larger public that higher education is not simply about educating young people to be smart, socially responsible and adequately prepared for whatever notions of the future they can imagine, but that higher education is central to democracy itself. Currently, he continues, universities are suffering from a crisis of legitimacy and a crisis of agency. Consequently, if universities are to regain their role as a public good, faculty, students and other groups outside of the university are going to have to engage in a range of acts of civil disobedience extending from occupying classrooms to mobilising larger populations in the street to force the hand of corporate power and its allies. In his interview with Samalavicius, it is Giroux's (2016) argument that:

Without the formative culture that makes democracy possible, there will be no critical agents, no foundation for enabling people to hold power accountable and no wider foundation for challenging neoliberalism as a mode of governance and political and ideological rationality. The struggle over higher education and its democratic misuse cannot be separated from the struggle to undo the reign of markets, neoliberalism and the ideologies informing this savage market fundamentalism. (Giroux \& Samalavicius 2016)

What, then, are the implications for 'transformation' in higher education in South Africa? What would a transformed university look like if it cannot be understood in terms of institutional merging and re-shuffling in an attempt to redress historical imbalances and inequities, or reductionist games of numbers (of black students)?

\section{Transformation as an enactment of democratic engagement}

I am of the opinion that Mouffe's (1992:30) notion of a 'social imaginary' - that is, the condition of possibility of the political community is at the same time the condition of impossibility of its full realisation - offers particular considerations for transformation in higher education in South Africa. Firstly, as Badat (2016:7) makes us aware, higher education is constrained by wider economic and social policies, which place major constraints on the pursuit of ambitious transformation goals. To this end, one would need to consider that not only does transformation not speak to all people in the same language but that understandings of transformation cannot be limited to goals. Instead, transformation has to be conceived as being embedded in the democratic engagement that continually gives meaning to be part of a democratic society. In this regard, Mouffe (1992:29) argues that the political community should not be seen as an empirical referent, but rather as a discursive surface. This means that the political community is constituted by a multiplicity of beings, expectations and demands - which means that there will always be those on the inside and those on the outside; those that are included, and those who are not.
Contrary to what neo-liberal ideologists would like us to believe, states Mouffe (2007:2), political questions - like those, related to transformation - always involve decisions which require us to make a choice between conflicting alternatives. While there are numerous liberalisms, some more progressive than others, states Mouffe (2007), the dominant tendency in liberal thought is characterised by a 'rationalist and individualist approach which is unable to grasp adequately the pluralistic nature of the social world, with the conflicts that pluralism entails; conflicts for which no rational solution could ever exist, hence the dimension of antagonism that characterizes human societies'. In this sense, transformation is necessarily underscored by tensions - tensions, which often, will remain irreconcilable. Consider, for example, the recent flurry of social media rants - all from 'educated' people - defined by vitriolic racism. Consider in particular a post by a postgraduate student, who vented racial slurs at the South African Minister of Sports for prohibiting three sporting codes from hosting major international events, owing to their failure to meet transformation targets (Feltham 2016). Transformation, therefore, has the inherent potential to both unite and divide. As such, it has to be considered in relation to what it awakens in people, and hence society. To associate or conflate conditions of transformation with that which is visible only - as in numbers or the removal of statues - is to only institutionalise it. Transformation is about changing the way one thinks, about the way one sees and engages with others, so that one changes what one does. In terms of the agonistic model, explains Mouffe (2007:3), the public space is:

$[T]$ he battleground where different hegemonic projects are confronted, without any possibility of final reconciliation ... According to the agonistic approach, public spaces are always plural and the agonistic confrontation takes place in a multiplicity of discursive surfaces. I also want to insist on a second important point. While there is no underlying principle of unity, no predetermined centre to this diversity of spaces, there always exist diverse forms of articulation among them ...

Transformation, therefore, is about being self-reflective inasmuch as it concerns acting as a critical agent in relation to institutional hegemonies. This is the social imaginary to which Mouffe (1992) refers, since it should never be realised. This is because the very realisation of transformation is in itself an end, since it implies that a certain condition or goal has been reached, and once that happens, transformation ceases. In this sense, the realisation of transformation both reveals and conceals that which is not immediately visible. This is not to say that transformation targets are irreconcilable with notions of democratisation. Indeed, transformation has to be made visible through concrete achievements of, for example, student access, the appointment of demographically representative academics or the decolonisation of university spaces.

Finally, given that understandings of higher education are always located, and hence defined by the political, social and economic contexts in which it finds itself (Badat 2016), 
and given that higher education is not simply about educating young people, but is central to democracy (Giroux \& Samalavicius 2016), one needs to consider that the particular challenges facing higher education are about societal challenges. Whatever transformation is being called upon within higher education is reflective of the type of transformation needed within society. Democracy, argues Giroux (2004), 'cannot function without educated citizens capable of being autonomous, making knowledgeable judgments, and bringing what they learn to bear on understanding and shaping civic culture'. This means, he continues, firstly, that higher education cannot be separated from the imperatives of an inclusive democracy, and secondly, that the crisis of higher education must be understood as part of the wider crisis of politics, power and culture (Giroux 2004). And, if higher education cannot be separated from the imperatives of an inclusive democracy, then higher education has to, as Giroux (2004) maintains, remain a site of resistance. Moreover, higher education has to be about the continual questioning of the boundaries of the political. To this end, it becomes the responsibility of higher education to hold to account the society in which it finds itself.

It seems most appropriate, therefore, to conclude with Derrida's (2004:148) contention that the public role of the university is 'the responsibility of a community of thinking'. To Derrida (2004:91), responsibility is equated with 'a summons requiring a response' (2004:91). That is, when people are summoned or called to act in a particular way by responding to a situation, they are said to act responsibly. When Derrida describes the university as 'the responsibility of a community of thinking' (2004:148), he is alluding to both its reason (to be) and its justification (for being). If the public role, therefore, of the university is to serve as a 'community of thinking', then such a community can never reach a transformed state, since such a state would bring into disrepute its capacity to both think and transform. For universities to become a 'community of thinking' would necessarily imply that they ought to engage with students' voices. Such engagement expands a 'community of thinking' to include all voices, and hence all conditions - even in its agonistic forms. If higher education is about continual questioning of the boundaries of the political, then such questioning has to include engagement with the issues of student access, fees and the decolonisation of spaces and curricula. In this regard, the responsibility of a university's 'community of thinking' is made visible through engaging with student debates and protests.

In this article, I have recognised that higher education, in its multiplex roles of social, political, epistemological and capital reform, is to both symbolise and enact transformation. By looking at current forms of transformation in higher education in South Africa - that is, political and institutional I have raised questions about the criticality of protest and violence in relation to transformation. I have also argued that a notion of transformation, which is only focused on visible outcomes - such as racial demographics in relation to student access, funding and the removal of statues - is limited. In considering what transformation might look like as an instance of democratic engagement, I have argued that transformation cannot be a goal within itself. Rather, that as a 'community of thinking' (Derrida 2004), higher education has a moral responsibility to not only present resistance but also to continuously aver towards transforming. In this regard, and in conclusion, transformation is like democracy that is, it is an unending and unpredictable process.

\section{Acknowledgements Competing interests}

The author declares she has no financial or personal relationships that may have inappropriately influenced her in writing this article.

\section{References}

Aronowitz, S. \& Giroux, H.A., 2000, 'The corporate university and the politics of education', The Educational Forum 64, 332-339. http://dx.doi.org/10.1080/ 00131720008984778

Badat, S., 2010, 'The challenges of transformation in higher education and training institutions in South Africa', paper commissioned by the Development Bank of Southern Africa, viewed 13 June 2016, from https://www.ru.ac.za/.../The $\% 20$ Challenges $\% 20$ of $\% 20$ Transformation $\% 20$ in $\% 2$ High

Badat, S., 2016, 'Deciphering the meanings, and explaining the South African higher education student protests of 2015-16', viewed 15 June 2016, from wiser.wits. ac.za/.../Saleem $\% 20$ Badat $\% 20 \% 20$ Deciphering $\% 20$ the $\% 20$ Meanings, $\% 20$ a

Barsoum, M., 2014, 'Cairo University engineering students begin strike to protest violence on campus', viewed 26 May 2014, from http://english.ahram.org.eg/ NewsContent/1/64/97138/Egypt/Politics-/-Cairo-University-engineeringstudents-begin-strik.aspx

Deem, R., 1998, “"New managerialism” and higher education: The management of performances and cultures in universities in the United Kingdom', Internationa performances and cultures in universities in the United Kingdom, International
Studies in Sociology of Education 8(1), 47-70. http://dx.doi.org/10.1080/ 0962021980020014

Department of Education (DoE), 1997, Education White Paper No. 3: A programme on the transformation of higher education transformation, Government Printers, Pretoria.

Department of Education (DoE), 1998, Higher Education Amendment Act, Government Printers, Pretoria.

Department of Education (DoE), 2001, National plan for higher education, Government Printers, Pretoria.

Department of Higher Education and Training (DHET), 2012, Green paper for postschool education and training, Government Printers, Pretoria.

Derrida, J., 2004, Eyes of the university: Right to philosophy 2, transl. J. Plug, Stanford University Press, Stanford.

Du Toit, A., 2000, 'Critic and citizen: The intellectual, transformation and academic freedom', Pretexts: Literary and Cultural Studies 9(1), 91-104. http://dx.doi. org/10.1080/713692703

Feltham, L. 2016. 'Mathew Theunissen's racist rant goes viral', viewed 25 July 2016, from mg.co.za/.../2016-05-03-twitter-erupts-after-matthew-theunissen-racist-ra

Giroux, H.A., 2004, 'An educator's reflections on the crisis in education and democracy in the US: An interview with Henry A. Giroux by Michael Alexander Pozo, 25 September 2004', viewed 1 August 2014, from www.dissidentvoice.org

Giroux, H.A. \& Samalavicius, A., 2016, Higher education and neoliberal temptation: A conversation with Henry Giroux, viewed 15 June 2016, from http://www.eurozine. com/articles/2016-05-04-giroux-en.html

Hall, M., 2016, South Africa's student protests have lessons for all universities, Higher Education Network, viewed 15 June 2016, from https://www.theguardian.com/ higher-education-network/2016/mar/03/south-africas-student-protests-havelessons-for-all-universities

Higher Education South Africa (HESA), 2014, 'South African higher education in the 20th year of democracy: Context, achievements and key challenges', HESA pres year of democracy: Context, achievements and key challenges', HESA presentation to the Portfolio Committee on higher education and training in
Parliament, Cape Town, 5 March, viewed 18 September 2015, from http://www. Parliament, Cape Town, 5 March, viewed 18 September 2015, from http://www.
hesa.org.za/hesa-presentation-portfolio-committee-higher-education-and-
training

Jansen, J., 2004, 'Changes and continuities in South Africa's higher education system, 1994 to 2004', in L. Chisholm (ed.), Changing class: Education and social change in post-apartheid South Africa, Human Science Research Council Press, Pretoria. 
Lange, M., 2012, Educations in ethnic violence: Identity, educational bubbles and resource mobilisation, Cambridge University Press, Cambridge.

MacGregor, K., 2016, 'The human costs of student tumult - An untold story', University World News, Issue no. 414, 21 May 2016.

Mouffe, C., 1992, 'Citizenship and political identity', The Identity in Question 61, 28-32. http://dx.doi.org/10.2307/778782

Mouffe, C., 2000, The democratic paradox, Verso, London.

Mouffe, C., 2007, 'Artistic activism and agonistic spaces', Art \& Research 1(2), 1-5.
Peters, M.A., 2007, Knowledge economy, development and the future of higher education, Sense Publishers, Rotterdam.

Sanborn, H. \& Thyne, C., 2011, 'Learning democracy: Education and the fall of authoritarian regimes', viewed 19 May 2016, from vmi.academia.edu/ HowardSanborn/Papers/1149456

Suttner, R., 2016, 'Op-Ed: Student protests, an indictment of "post-apartheid" South Africa', viewed 14 June 2016, from www.dailymaverick.co.za/.../2016-02-11-oped-student-protests-an-indictment-of-po 